\title{
Mixed Teaching of "MATLAB Simulation and Application" Course Based on "Micro Course + Flipped Classroom"
}

\author{
Hai-jun Wang ${ }^{a *}$, Tao Jin ${ }^{b}$ \\ Department of Mathematics and Computer Engineering, Ordos Institute of Technology, Inner \\ Mongolia Ordos, 017000, China \\ a*email:592870577@qq.com, bemail: 50204040@qq.com \\ ${ }^{*}$ Corresponding author
}

\section{Keywords: Micro Course, Flipped Classroom, Mixed Teaching, MATLAB}

\begin{abstract}
MATLAB simulation and application" is a theoretical and practical course, with numerous knowledge points and many practical operations. Traditional classroom teaching is difficult to complete the teaching of teaching knowledge points in limited class hours, and the teaching situation is not ideal. Based on this, this research adopts the combination of "micro course + flipped classroom" and traditional classroom in the teaching of this course for mixed teaching. The results show that this mixed teaching can not only effectively promote teaching reform, but also significantly improve students' practical ability and cultivate their self-learning ability.
\end{abstract}

\section{Overview}

With the continuous advancement of the new curriculum reform of the Ministry of Education, China's higher education teaching model has made a major breakthrough. In particular, the development of Internet information technology provides a technical basis for the modern higher education curriculum reform, while micro course and flipped classroom as a new teaching model provide a new way for college teaching reform. As a professional elective course, "MATLAB simulation and application" not only has many theoretical knowledge points, but also contains a lot of practical teaching content, which is of great significance to improve students' logical thinking ability and cultivate their ability to analyze and solve practical problems. However, the same problem exists in MATLAB teaching in various universities, that is, the total class hours are relatively few, so it is inevitable that there will be some problems in the teaching, and many students will use the knowledge points are abandoned. So how do you teach and practice more content without increasing class hours? The emerging teaching form of "micro course+ flipped classroom" can well solve this problem.

\section{Application of micro course in flipped classroom}

\subsection{The concept of micro course}

Micro course was put forward by David Penrose, senior teaching designer of SAN Juan college, new Mexico, USA in 2008. It mainly refers to the actual teaching content designed by constructivist methods for online learning or mobile learning, so David Penrose was dubbed as "professor in one minute" [1]. Meanwhile, with the emergence of new terms such as flipped classroom and khan academy, micro course has gradually become familiar to people. In 2012, Professor Hu Tie-sheng gave the definition of micro course: micro course is based on Micro-teaching video as the main carrier. Teachers carefully design and develop a situational and multi-learning support for a certain subject knowledge points (such as key points, difficulties, doubts, test points, etc.) or teaching links (such as learning activities, experiments, tasks, etc.). Miniature online video network course [2]. In 2013, professor Li Jia-hou defined micro course as a small course that is within 10 minutes, has clear teaching objectives, short content and focuses on one problem [3]. Compared with traditional courses, the content shown in table 1 can be obtained by analyzing the above definitions of micro course by domestic and foreign scholars. In the era of Internet plus, micro-course as a new teaching resource, adding it to teaching, is not only a supplement to the traditional curriculum content, but also a new, 
personalized online learning method.

Table 1 Comparisons between Micro Course and Traditional Course

\begin{tabular}{lll}
\hline & Micro Course & Traditional Course \\
\hline Course objectives & Clear goals and prominent themes & $\begin{array}{l}\text { According to the outline and training } \\
\text { objectives set }\end{array}$ \\
\hline Course content & $\begin{array}{l}\text { A knowledge point or teaching } \\
\text { activity }\end{array}$ & The teaching material content \\
\hline Learning style & Mainly video streaming media & The traditional teaching \\
\hline $\begin{array}{l}\text { Teaching } \\
\text { arrangement }\end{array}$ & Flexibility, freedom & Follow the teaching plan \\
\hline Teaching duration & About 10 minutes & About 45 minutes \\
\hline Teaching place & Arbitrary Places & Fixed classroom \\
\hline Teaching form & Autonomous learning & Teacher-led learning \\
\hline Teaching subject & Student & Teacher \\
\hline
\end{tabular}

\subsection{Flipped classroom concept}

Flipped classroom, or inverted classroom, is a new teaching mode that reverses the traditional classroom teaching structure and enables students to complete the learning of knowledge before class and complete the absorption and mastery of knowledge in class [4]. In 2000 Maureen Age, J. Wesley Baker formally proposed the concept of flipped classroom in his paper flipped classroom: using online course management tools to make teachers mentors around students, published at the 11th international university teaching and learning conference [5]. After 2007, influenced by the development of khan academy, flipped classroom was widely concerned by educators at home and abroad [6]. Compared with traditional classroom, flipped classroom reverses the two teaching processes of knowledge transmission and knowledge internalization. Knowledge transfer is not completed through traditional classroom, but through information technology after class. Knowledge internalization is completed with the help of teachers and classmates in class. With the inversion of the teaching process, various links in the process of classroom learning have also changed. The comparison of elements of traditional classroom and flipped classroom is shown in table 2 .

Table 2 comparison of elements in traditional classroom and flipped classroom

\begin{tabular}{lll}
\hline Teacher & Traditional classroom & Flipped classroom \\
\hline Student & $\begin{array}{l}\text { Knowledge imparter and classroom } \\
\text { manager }\end{array}$ & Learning Instructor \\
\hline Teaching forms & Passive receiver & Active researcher \\
\hline Class content & Knowledge dissemination & Pre-class learning + classroom inquiry \\
\hline $\begin{array}{l}\text { Technology } \\
\text { application }\end{array}$ & Content show & Problem exploration \\
\hline Evaluation way & Traditional paper test & $\begin{array}{l}\text { Independent learning, communication and } \\
\text { reflection }\end{array}$ \\
\hline
\end{tabular}

\subsection{Organic combination of micro course and flipped classroom}

Micro course is the core and foundation of flipped classroom implementation. Teachers can clearly present knowledge points to students after class through micro course, and students can carry out independent learning according to specific teaching tasks. The premise of active and smooth implementation of flipped classroom teaching is to effectively complete micro class learning. Flipped classroom teaching has become the embryo body of micro course development. Only when micro course is rooted in flipped classroom teaching mode can it truly exert its power, and many scattered micro courses can become a system. Therefore, micro course and flipped classroom complement and promote each other. Based on the above relationship between micro-class and flipped classroom, this study introduces the microcourse + flipped classroom teaching mode into the teaching reform of MATLAB simulation and application, and designs the mixed teaching process of micro course + flipped classroom as shown in Fig.1. 


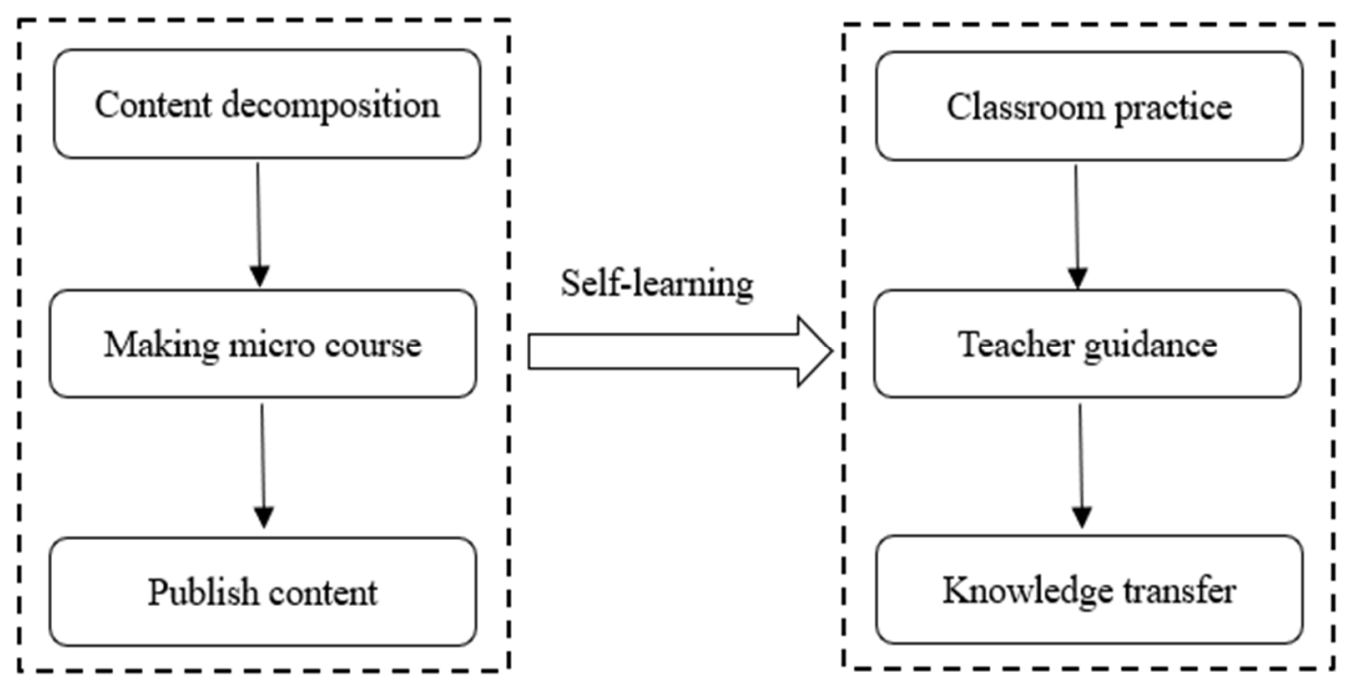

Fig.1. mixed teaching process of micro course and flipped classroom

\section{Mixed teaching design of "MATLAB simulation and application"}

\subsection{Content decomposition}

This study takes the course "MATLAB simulation and application" of electronic information science and technology, automation major, department of information engineering of our hospital as an example. This course involves 7 parts in total, and it takes about 48 class hours to complete the teaching of the teaching content. The specific content distribution is shown in Fig.2. But in the department of information engineering training scheme, the course is a professional elective course, only 2 credits, 32 hours, according to the school can not complete the teaching contents of teaching, but if you can't finish all the teaching content, both for the subsequent course of study for students graduation design in the future, will have great influence, so in the original teaching mode, can only be part of the practice content to students self-study, and then for counseling courses through practice. However, due to the poor foundation of most students and their self-learning ability, it is difficult to complete relevant self-learning tasks. Therefore, the actual teaching process, a lot of content can not be fully taught. However, with the two teaching methods of micro course and flipped classroom, this course can carry out good teaching reform. Practical teaching content is only taught the most basic content, while further practice is mixed teaching through "micro course + flipped classroom".

Course system of MATLAB simulation and Application

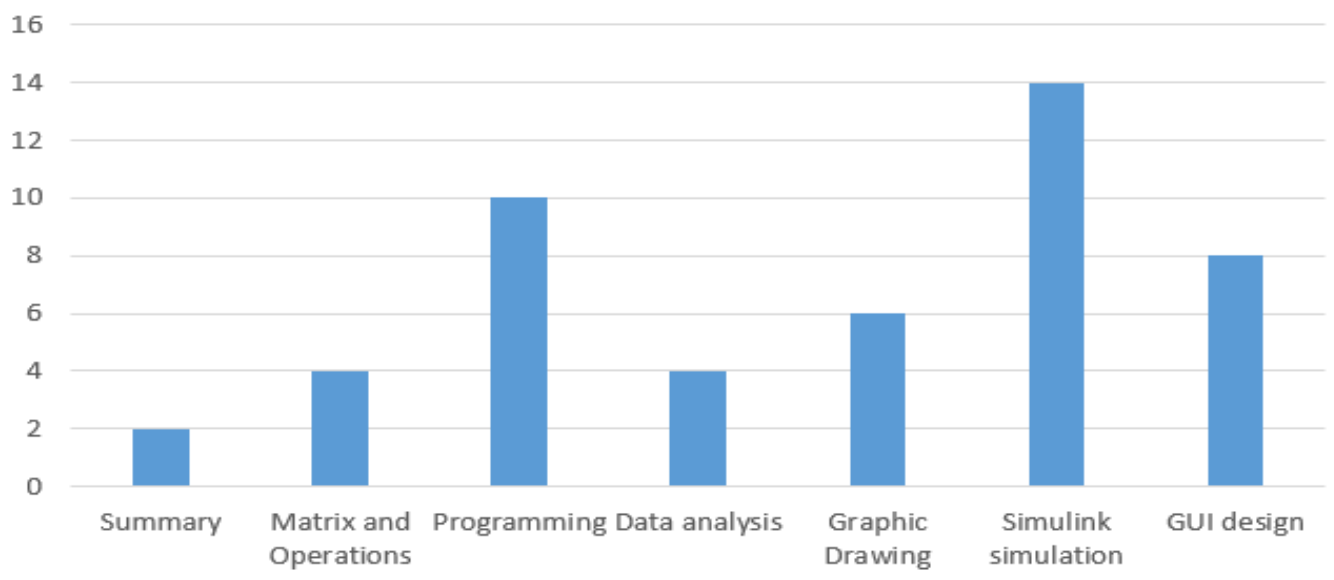

Fig.2. distribution of class hours in "MATLAB simulation and application"

\subsection{Micro course making}

"Micro course + flipped classroom" teaching is of great significance to improve the learning of this course. Therefore, each practical knowledge point can be divided into concept teaching and specific 
application according to the knowledge point, and the content of specific application can be recorded into micro-video. Each micro-video is short and concise, distinct theme, the length of control in 10 minutes. Then, flipped classroom teaching can be carried out for all these contents, assigning tasks to students. Students can learn freely outside class, and focus on exercises in class, and explain the problems in the practice process, so as to improve students' understanding of practical contents. Micro course tools using Camtasia Studio, the software is powerful, especially for video editing features, of course, make the class content mainly based on practical demonstration, such as to the problem of circuit simulation in the Simulink simulation, made 6 minutes and 51 seconds long micro class content, through an example that tells the main tools used, and explained the circuit design, teaching content integrity, short.

\subsection{Implementation of "micro course + flipped classroom"}

With the popularity of mobile client terminals, some terminal applications have become an indispensable part of our daily life, such as qq and WeChat. In this study, the realization of "microcourse + flipped classroom" teaching mode is mainly based on WeChat public account. In this work platform, teachers first create corresponding courses, and students enter corresponding courses by scanning code. Teachers can find students in corresponding courses, upload corresponding course resources, and assign relevant tasks to students through the release of homework. Students in the client will receive the corresponding teaching resources, corresponding homework tips. In this way, we can directly see the learning situation of students through the submission of homework on WeChat official account, give corresponding instructions to students, and ask corresponding questions to students. At the same time, students can communicate with teachers about the corresponding problems, which has a good interaction.

\subsection{Teaching practice}

The content discussed in this study has been carried out corresponding teaching practice in the course of MATLAB simulation and application taught by the author. After the course reform of "micro course + flipped classroom", the corresponding teaching content has been taught, and the course has also promoted the reform of course assessment. Table 3 shows the comparison of assessment methods before and after the reform. The assessment methods after the reform pay more attention to students' practical ability. Finally, students' scores also showed that "micro course + flipped classroom" and traditional classroom were adopted for mixed teaching of MATLAB simulation and application. It can not only cultivate students' thinking independence and learning autonomy, save a lot of class time, but also effectively stimulate students' learning enthusiasm and improve their learning efficiency.

Table 3 reform ideas and schemes of assessment methods

\begin{tabular}{lll}
\hline \multicolumn{1}{c}{ Before the reform } & \multicolumn{1}{c}{ After the reform } \\
\hline $\begin{array}{l}\text { Assessment } \\
\text { ratio }\end{array}$ & $\begin{array}{l}\text { 30\% of the usual assessment, 70\% of the } \\
\text { final assessment }\end{array}$ & $\begin{array}{l}30 \% \text { of the usual assessment, 70\% of the final } \\
\text { assessment }\end{array}$ \\
\hline $\begin{array}{l}\text { Ordinary } \\
\text { assessment }\end{array}$ & Attendance 10\%+20\% of the period & $\begin{array}{l}\text { (Attendance, classroom work) } 10 \%+\text { mid- } \\
\text { term exam 10\% + end-time major assignment } \\
10 \%\end{array}$ \\
\hline $\begin{array}{l}\text { Final } \\
\text { assessment }\end{array}$ & $\begin{array}{l}\text { Fill in the blanks, multiple choice } \\
\text { questions and program design written } \\
\text { test }\end{array}$ & $\begin{array}{l}\text { Fill in the blanks, multiple-choice written test, } \\
\text { comprehensive design machine test }\end{array}$ \\
\hline
\end{tabular}

\section{Summary}

In this paper, the application of "micro course + flipped classroom" teaching mode in "MATLAB simulation and application" is discussed, and the decomposition of course teaching content, production of micro course and realization of interactive learning mode are discussed. This hybrid teaching mode, which combines micro-video flipped classroom teaching mode with traditional teaching, changes the teaching concept of teachers and plays a good role in improving the teaching 
and research level of teachers. At the same time, to a certain extent, overcome the long time dependent on teaching students learning habit of teachers "teaching", to develop the students' ability of selfstudy, explore problem ability has the very good effect, of course, the implementation of the premise condition of this kind of teaching pattern is class capacity not easy too, best can control within 50 people, is advantageous for the teaching management.

\section{Acknowledgment}

This research was financially supported by University-level education reform project of Ordos Institute of Technology (Grant NO. 20180212)

\section{References}

[1] Le-ming L, Amp C Q, Baohui Z. Research on a Micro-lecture Design Model through Comparative Case Study. Open Education Research, vol.19, iss.1, pp:65-73,2013.

[2] Tie-sheng H, Chun-qing Z. Regional Practice and Enlightenment of High-quality "Micro course" Resources Development in Primary and Middle Schools.The Chinese Journal of ICT in Education, iss.22, pp:65-69,2012.

[3] Jia-hou L.The meaning and development of micro-course. Information technology for primary and secondary schools, iss.4, pp: 10-12,2013.

[4] Bing-Chao P. Quasi-experimental Study on Flipped Classroom's Impact on the University Teaching Effect. Modern Educational Technology, vol.24, iss.12, pp:84-91, 2014.

[5] Hong-yun Y, Xu-hui C. Literature metrological analysis of flipped classroom research at home and abroad. Higher Education Exploration, iss.4, pp:78-85, 2016.

[6] Li-bing J, You-qing C. The Quasi-experimental Study on the Effectiveness of Colleges Liberalarts Courses Based on Flipped Classroom. China Educational Technology, iss.7, pp:107-113, 2016 